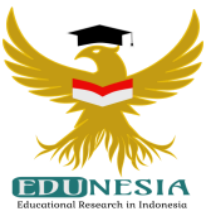

\title{
Human Resource Management in Improving The Quality of Education
}

\author{
Darul Qutni ${ }^{1}$; Muhammad Kristiawan²; Yessi Fitriani ${ }^{3}$ \\ 1,3Department of Education Management, Universitas PGRI Palembang, Indonesia. \\ ${ }^{2}$ Department of Education, Universitas Bengkulu, Indonesia. \\ ${ }^{1}$ Corresponding Email: darul.qutni1969@gmail.com, Phone Number : 0812 xxxx xxxx
}

\author{
Article History: \\ Received: Jan 03, 2021 \\ Revised: Feb 09, 2021 \\ Accepted: Feb 16, 2021 \\ Online First: Feb 20, 2021
}

\section{Keywords:}

Human resources, management, quality of education.

Kata Kunci:

Manajemen, mutu pendidikan, sumber daya manusia.

\footnotetext{
How to cite:

Qutni, D., Kristiawan, M., \& Fitriani, Y. (2021). Human Resource Management in Improving The Quality of Education. Edunesia: Jurnal Ilmiah Pendidikan, 2 (2): 354366

This is an open access article under the $C C$-BY-NC-ND license (c) $(1) \ominus$
}

\begin{abstract}
: this study aims to determine human resource management in improving the quality of education. The formulation of the problems in this research are: (1) how is human resource management in improving the quality of education?, (2) what are the obstacles faced in the implementation of human resource management in improving quality?, (3) what are the factors in the implementation of human resource management in improving the quality of education?, (4) how is the quality of education?. This research is a qualitative research with a qualitative descriptive approach. The data obtained were collected through observation, interview and documentation techniques. The results showed that human resource management at SD Negeri 170 Ogan Komering Ulu (OKU), both in quality improvement, implementation, supporting factors and the quality of education had been running optimally.
\end{abstract}

Abstrak: penelitian ini bertujuan untuk mengetahui manajemen sumber daya manusia dalam peningkatan mutu pendidikan. Rumusan masalah dalam penelitian ini adalah: (1) bagaimana manajemen sumber daya manusia dalam peningkatan mutu pendidikan?, (2) apa kendala yang dihadapi dalam pelaksanaan manajemen sumber daya manusia dalam peningkatan mutu?, (3) apa saja faktor dalam pelaksanaan manajemen sumber daya manusia dalam peningkatan mutu pendidikan?, (4) bagaimana mutu pendidikan?. Penelitian ini merupakan penelitian kualitatif dengan pendekatan deskriptif kualitatif. Data yang diperoleh dikumpulkan melalui teknik observasi, wawancara dan dokumentasi. Hasil penelitian menunjukkan bahwa manajemen sumber daya manusia di SD Negeri 170 Ogan Komering Ulu (OKU) baik itu dalam peningkatan mutu, pelaksanaan, faktor pendukung dan mutu pendidikan sudah berjalan dengan optimal. 


\section{A. Introduction}

Education quality determines the quality of the people to live in the developed and dignified. UU No 20 the year 2003 on system education in national started to carry update curriculum, improvement in capability of educators, the provision means and infrastructure, improvement in well-being of educators, improvement organizational, management, and supervision. Essential for implemented, associated with improvement in the quality of the supply power human. Management is most often discussed in the field of academic and practice.

Education aims to provide human resources for national development. The development step is always strived to be in harmony with the records of the times. The times have always brought new things that never appeared before. According to Kemal \& Hasibuan (2017) states that resource management requires human beings and the awareness needed in humans as a source that only takes the potential and is decided in an organization, and needs to continue to be developed so that it can contribute as much as possible to the organization and to development itself. The progress of science and technology in developing countries is determined by management resources taken from humans, called human resource management, this is the dominant factor in this field.

Increasing the quality of management resources leads people to see the concept in the totality of life, the dimensions of quality that lie in the context of the development as a whole, namely good faith and professional service, intellectual discipline and efficiency (Suryadi et al, 2020). The phenomenon of social at a time now and time the era of globalization a was decide was management resources human (Ruhana, 2012). Human resources are the most important capital of all activities. Humans as the most important element are analyzed and developed in ways, time, energy and abilities that can actually be used optimally for the benefit of organizations and individuals (Fathoni, 2006).

Human resource management is a science and art that regulates the process of utilizing human resources and other effectively and efficiently to achieve a goal (Almasri, 2016). With era full and change, environment in which faced by management source take human challenge, change appear to quickly and include issues which very wide. managing resource take the human in a was decide for success an organization, fail in the image would have an impaction difficulties organizations in the ideal in various challenges (Widiansyah, 2018).

According to Kemal, et al (2019) human resource management is a factor that will determine organizational performance, the appropriateness of utilizing and developing human resources and integrating them in a unified movement and direction of the organization will be important for increasing organizational capabilities in achieving its goals. In order to better understand how the position of human resource management in an organizational context requires an understanding of the meaning of human resource management itself, in order to position the role of human resource management in the dynamics of organizational movements (Iskarim, 2017).

The importance of human resource management can't be separated from human efforts to develop an increase in the quality of human resources. The participation of human resources in development requires awareness without coercion and that is the essence of the role of human resources in expected development.

One of the important areas in education management is related to human resources involved in the education process, both educators such as teachers and education personnel such as administrative personnel. The intensity of the world of education in relation to 
humans can be seen as an important difference between school educational institutions and other organizations.

This is how that had source take human in was dominant in the process in education or instruction, a thing has also mean know that manage human resource is fielded a very important an implement process educational or learning in school improve the performance of human resource need management systematically and targeted, so process performance objectives in the organization can implement an effectively and efficiently. This mean knows that management source takes human a thing was key to successful companies, or small, anything type in the industry (Mufidah, 2018). Aspect management source takes human is it in the position key in a company or an organization because every organization formed in the people, use services in them, developed skill in them, encourage they're to performing high, and guarantee it hose for continue keep a commitment to the organization was the was key in achieving objectives organization.

As a formal educational institution, in the implementation of education, it is highly determined that the quality improvement is in response to the needs and dynamics of a developing society, so that quality improvement can be realized through the implementation of education. School services can be said to be of high quality or quality if they are made simple but important and meet standards. That is, the product must be precisely fit for purpose. Basically, the quality of education can be viewed as a condition, condition, appearance or performance shown by each component of the education unit in achieving the stated goals.

According to Dewi (2013), human resource management in order to improve the quality of education is very important. This means that in an organization or educational institution it can advance or develop with the support of human resources. Every educational institution or organization that wants to develop must pay attention to human resources and manage them well, in order to create quality education. The success of education in schools is largely determined by the success of the principal in managing educators and education personnel available at schools. In this case, increasing productivity and work performance can be done by improving the behavior of teachers and education personnel in schools through the application of various personnel management concepts and techniques. In human resource management, the principal is the key to success in achieving quality education. The principal is required to always strive to foster and develop human resources or educators and education staff in order to create quality education.

Educators/teachers are a very important human resource in an educational institution (Winarti, 2018). This is because they are front-liners who deal directly with students so that the success or failure of students lies in a teacher in the learning process. The process of recruiting and coaching educators is something that is vital. In the case of teacher recruitment, of course, it does not only consider the academic side, but there are other requirements that must be met, namely they must have a good personality, have integrity and be responsible for something they carry.

In a good organization, it also needs good management. Therefore the need for a good management understanding is very important. Where the entire process of implementing an educational institution requires a mature management foundation. The three management functions in modern management are not linear, but a spiral. This allows the organization to move continuously and not stop at one stage.

The most important thing in a company or educational institution is to socialize its employees into the company so that they can become productive and effective employees. 
Since the direct placement of employees on the job does not guarantee that they will succeed and they often feel uncertain about their roles and responsibilities, there is a need for training and employee development. Through training, employees are helped to do existing jobs, and improve their overall career and help develop their responsibilities in the future. If training is more oriented towards present conditions, while development is more oriented towards the future (Mangkuprawira, 2008).

One of the functions of human resource management is training and development, meaning that to get an educated workforce with good and appropriate human resources, it is necessary to hold training and development (Yuniarti, 2019). This is an effort to prepare the education workforce to face job assignments that are considered to have not mastered it. At SD Negeri 170 OKU educational institutions are educational institutions that pay attention to the quality of education. Efforts are being made to maintain and improve the quality of education, namely by holding training by the school for educators and education personnel so that it is recognized by the wider community that the quality or quality of education at SD Negeri 170 OKU really fulfils the wishes of customers.

\section{B. Method}

This research is a qualitative study using a qualitative descriptive approach. The choice of this method is based on the consideration that data is taken that illustrates the understanding of the school manager, in this case, the principal, teachers, administration, employees and the financial department (treasurer) on human resource management at SD Negeri 170 OKU which includes, the human resource planning process, the recruitment process, selection and placement, the training and development system, the compensation system and the appraisal system and the monitoring system. Besides that, this approach also aims to gain insight and interpretation in-depth and naturally about the meaning of phenomena and realities that appear in the field.

Qualitative research places more emphasis on process aspects than just results. Qualitative research has a natural field as a direct source of data so that it is descriptive naturalistic. In line with the above opinion, this study aims to describe the understanding of school administrators of human resource management at SD Negeri 170 OKU and the programs that have been implemented.

Meanwhile, the presence of researchers in qualitative research is necessary, because there is a close relationship between researchers and research subjects. As the main instrument, humans have a high degree of adaptability in research, can always adapt to changing situations in research (Nasution, 1992), meaning that researchers as instruments bear the consequences that researchers become everything from the entire research process, namely as a planner, implementer, data collector, data analysis and at the same time as a pioneer of research data.

The researcher wants to reveal the meanings and context of behaviour and the processes that occur in the observed pattern of factors related to the perceptions possessed by the participants. In this connection, to obtain a complete, in-depth and through understanding of the research focus, the approach that is considered suitable in this research is the phenomenological approach. Thus the data obtained, both in the form of information, observation symptoms, information and observations about "human resource management in improving the quality of education at SD Negeri 170 OKU" is more appropriate if it is expressed in words by the characteristics of the qualitative approach. to obtain a deeper and broader understanding of the observations behind the information and observations during 
the field. The data obtained were collected through observation, interview and documentation techniques.

\section{Result and Discussion}

\section{Human Resource Management in Quality Improvement}

The author presents the discussion of research findings at SD Negeri 170 OKU based on the results of interviews, documentation and observations made formally or informally. Formal and informal interviews, observation and careful documentation were carried out directly by the researcher. The discussion of the research findings is as follows.

\section{a. Human Resource Planning System}

Human resource planning in education is of course very different from human resource planning in the business world and industry. In the business world and usually, some divisions or departments specifically manage human resource. In contrast to the world of education in this case schools, therefore human resource planning is usually carried out by the principal or a team that has been formed. Likewise, what happened in SD Negeri 170 $\mathrm{OKU}$, this is based on the results of interviews that have been conducted with the principal both formally and informally, that those directly involved in management and planning are the head of the school, for teachers and school treasurers. SD Negeri 170 OKU, which has been carried out so far, is using volume analysis and workload, which in other terms is called tupoksi (main objectives and functions) and then looking for the right personnel to fill the position or position with various considerations.

Human resource planning is also carried out through several stages such as making the main tasks and functions first in terms of what the workload is, then finding and selecting the right personnel to do the task. In filling in personnel, besides being based on intellectual capacity, capability and experience, it also considers academic achievement and skills. Job analysis and job descriptions.

Job analysis is an activity of the process of collecting and compiling information related to the tasks, types of work and responsibilities of each position or job to realize organizational goals, both present and future. This job analysis should be as detailed and clear as possible starting from duties and responsibilities of a person who occupies the top position to someone who occupies the lowest position so that there is no overlap of work.

The analysis of jobs and positions has been carried out in several stages, including (1) drafting by the principal and the appointed team, (2) discussion in plenary meetings, (3) plenary meetings, (4) making and stipulation of certificate. (Interview with MD) what was conveyed was true that "the considerations used as a basis in conducting job analysis include the number of students, the number of activities and programs that must be adjusted, besides that additional support for infrastructure and financial strength is needed to achieve the goal".

The draft or initial concept of job analysis that reflects the main tasks and functions of all school components starting from the principal to the lowest level is not only 
formulated or compiled by the principal as a party but is formulated and compiled by the former team.

\section{b. Human Resources Recruitment, Selection and Placement System}

Recruitment of teachers, employees or new employees for an organization has always been a challenge in itself for the organization, including educational institutions. This activity is a continuation of human resource planning, usually, this human resource need is known with certainty after prior analysis in planning. Sometimes many organizations are faced with sudden requests to fill vacancies quickly and precisely due to conditions outside of planning, for example, when one day in the middle of the semester there is a non-permanent teacher who is appointed as a civil servant and is placed in another school, it must be filled as soon as possible and whatever the reason is for a vacuum in an organization, what is clear is that it must be filled and resolved immediately.

While the selection is the selection of a certain person from prospective employees or potential employees to carry out a position. This process begins after a collection of eligible applicants is obtained through recruitment. Thus the selection process is a series of activities used to decide whether to accept or reject. Therefore, the selection must be carried out appropriately to obtain a prospective workforce that fits the needs, both in quality. as well as quantity and by the expectations and goals of the organization.

From the research conducted, it was found that the recruitment and selection process for prospective teachers and employees or employees at SD Negeri 170 OKU was carried out in several stages: (1) Seeing the formation needed, (2) delivering announcements, (3) making summons, (4) interviews and (5) admission and placement.

Academic and non-academic achievement criteria are also standards that apply to all applicants, both general applicants and applicants who are still kinship with the principal, teachers and even the district education office.

As for the placement of non-permanent teacher candidates who have passed the selection, this is done through two models, namely: First, by direct placement which is usually applied for non-permanent teacher recruitment. Second, through apprenticeship, which is usually applied in the recruitment of non-permanent teacher candidates.

\section{c. Human Resources Training and Development}

Training is as a systematic change in the behaviour of employees or employees in an issue of a direction to enhance those organizational goals, it is a form of activity that aims to provide skills that are by their work so that they can quickly adjust their ideals to changing ideas. In training, an environment is created where employees or employees can learn attitudes, abilities and expertise, knowledge and specific behaviours that are related to work. Training is usually focused on professional provision for teachers, employees or employees who help them to categorize the weaknesses in their performance will come.

As for some of the programs that have been carried out in the form of training that has been carried out in SD Negeri 170 OKU at the end of the end are training for the teaching profession, KTSP, KK 13, computers, libraries and others. There are still other training, including training for prospective school principals for those who are interested in nominating themselves to become school principals, of course, with predetermined requirements. In addition to conducting training in the institutional environment itself, SD Negeri $170 \mathrm{OKU}$ also includes teachers and employees to take part in external training in 
institutional settings according to the invitation. iBoth at the district or provincial level, even up to the international level.

All teachers and employees have the same side to take part in training as well as in and outside the agency. Many types of training are supposed to be carried out that have planned in an immature way, as well as during implementation, in terms of impact, and funding. Usually, training outside the official institution changes so that it includes teacher or employee outside training, which means equalization so that everything will have the same experience and knowledge. After the implementation of the activities in ide in or outside the agency, there is always an effort to be evaluated and the accountability reports which are then followed up with the form of actual works such as the creation of a learning device or an socialization of the results of training.

\section{d. Human Resources Evaluation System}

The human resource evaluation system or often known as performance appraisal is an activity to measure or assess whether for a teacher or an employee it is success or failure in carrying out its work by using the standard of work is as a measure of measure.

This evaluation system aims at least: First, to provide a basic idea for planning and implementation of giving awards to teachers and employees for their performance in the previous period (to reward past performance), and second, to motivate the employees to get the employees who want to work it can be further improved (to motivate future performance improvement).

The evaluation system that is done in SD Negeri $170 \mathrm{OKU}$ is through speaking, namely: First, the monthly evaluation is done to evaluate the trip of the school program during one month and the absorption of the cases that are in the form of illusions, such as activities. Second, the meeting is evaluated in the middle of the year or at the end of the semester. Third, it can be evaluated at the end of the year of study. This is done to evaluate school trips for one year. The result will be used the guidelines for making School Activities Plan and Budget and the next School Income and Expenditure Budget Plan.

In addition to the evaluation, the evaluation is also carried out an incidental evaluation with a case study that will be completed soon. Evaluation of the implementation of the work program is generally valid, which means that it is applied to teachers and employees as well as the status of government employees, non-permanent teacher. Because all of the following contribute to the success of the teaching and learning process in school ideology. Criteria or benchmarks are used as an ideal comparison in determining the ideal failure of a teacher or an employee in carrying out the task of using the function of supporting functions as a standard of work.

Specifically for civil servants, as teachers or employees in the implementation of ideal assessment, in addition to using that, the function is as said above the idea and how many other supporting factors, including the assessment of employee work goals, is a means of evaluating the performance of civil servants which are made up of all the central government institutions, which are valid for all institutions. The employee work goals that is evaluated the teacher's performance is less evaluative because it is not fundamental to the standard of work, and the standard of work is always different. The existence of TPA (Teacher Performance Assessment) using employee work goalsis by work standards. With the argument that it is based on different performance, and that monitoring has been carried out continuously, and the assessment is imperative, without such an assessment no one is good and it is bad. 
As is the case with human resource planning, the implication in evaluating this performance is even though the final authority for the leadership is the highest, in this case, the head of school, but in practice, it still involves teachers or other employees.

\section{e. Compensation System}

Management of compensation is an important function in an ideal organization and usually is part of the idea of responsibility for the institution concerned. One of the most important if cases are the idea of a job where most of the employees are paid. Teachers or employees ideally should be paid equal to the qualification which is irrelevant to the job and the number of employees in the workforce who have that qualification. Compensation is a financial reward and services and benefits that are received by in-laws or employees as part of an employee relationship. Compensation is also what teachers or employees receive as a substitute for their contribution to the organization.

In the framework of providing compensation for teachers or employees according to educational specifications, the level of labour costs and responsibilities and risks for work in SD Negeri 170 OKU implements a compensation system in terms of salary for civil servants and honorarium for non-permanent teacher employees is as follows.

a) The salary of a civil servant teacher who pays is the state salary received according to rank and class.

b) Non-permanent teacher honorarium is paid with the allocation of school operational assistance funds and assistance from the guardian of new students who receive an average of Rp. 350,000 to Rp. 450,000 per month, the payment system is adjusted according to the length of sservice and level of education and workload.

Teachers, apart from receiving monthly salaries or honoraria, also receive structural allowances, extracurricular teaching, holiday allowance and 13th salaries. Also, for nonpermanent teacher, they receive allowances from the central, provincial or district governments.

\section{f. Supervision System}

The management system of supervision or control is basically an attempt to provide instructions for the inmates to implement the program so that the implementation of the program is in accordance with the provisions that have been mutually agreed upon. The surveillance system in SD Negeri $170 \mathrm{OKU}$ is an idea with standard determination, activity supervision, inspection and comparison of results with standard and activity correcting activities or standards.

\section{Implementation of Human Resource Management}

The implementation of human resource development management in improving the quality of education at SD Negeri 170 OKU As an issue of an if the normal educational institution, in the implementation of education it is very important that there is an increase in quality is as an answer to the needs of ideas and ideals of a society that is developing so that increasing the quality of ideas can be realized through faith man. School services can be said to be of quality or quality if they have met the standard. This means that the product must exactly match the aims of education. In principle, the quality of education can be viewed as an issue of state, condition, appearance or performance that is shown by each component of the educational unit in achieving that objective that has been defined. 
The implementation of the development of religious ideals needs to be done in a planned and sustainable manner. For development to be carried out properly, it must first be determined that the issue of a development program is the source of the human ideal. And to define a development program, management is needed to study a series of activities that are directed to utilize the resources of organizational ideals or institutions that are effective and efficient, through planning, organizing, giving orders / directing ideas and supervision.

\section{Supporting Factors for Human Resource Management Implementation}

The factors that support the implementation of development at SD Negeri 170 OKU are as follows: the problem of technology and sophistication is fast, it is time to experience a change in the idea of technology is one other technology, the change is fast and it continues to be continuous in the knowledge of skills, the emergence of knowledge and skills. The emergence of new schools that have an impact on the competition for education, follow the IPs and marketers and provide the best services to customers. Also, the availability of ideal facilities in conducting research, such as space, liquid crystal display, sound system, books, papers, and so on.

This was conveyed by School Principal Edi Wiranto, S.Pd. Sd as follows: "We have anticipated this problem. We understand to our friends how the coming year will be better than the previous year. With the splendour of technology, the sophistication of technology information, the emergence of new schools, providing good service, following market share, following existing customers, all of these have been discussed at the beginning of the year and will always be reminded at other meetings. "(W. 1 . c. 01)

"We have previously explained, the supporting factors in the implementation of the training, namely the liveliness of technology, the sophistication of technology information, the emergence of new schools, providing good service, following market share, following existing customers. Apart from that, there are facilities for training, such as liquid crystal display, sound system, books, papers and so on ". (W. 3. a. 01).

The statement above was also clarified by the fourth-grade teacher, Ms Nur Syafa'atin, S.Pd.I, (W. 1. c. 03) stated as follows: factors that support the implementation of training for educators, namely: 1) because of a lack of work experience, 2) because of competition with other schools, 3) because of the demands to know, study, follow the development of science and technology, 4) because we are educators have different backgrounds". And this is confirmed by the statement of Mrs Fathoniyah, S.Ag, which is as follows: "It has been explained previously by Ms Nur Syafa'atin, S.Ag that the supporting factors are 1) due to a lack of work experience for educators, 2) because of competition with other schools such as superior public elementary schools, 3) due to demands to know, study, follow the development of our science and technology, a teacher must not be clueless (stuttering technology), 4) because we educators have different backgrounds, some are from rural, urban, S2, S1, D3 graduates and others etc".

Supporting factors in the implementation of development at SD Negeri 170 OKU are: the problem of transferring technology and fast technology information sophistication has experienced a technology change is one such technology. The changes are fast and continuous in knowledge and skills (in this section, educators are required to be able to follow developments in science and technology in the world of education).

Demographic changes (educators who have different backgrounds) with the presence of training are so that they can communicate and work together harmoniously. 
The emergence of global competition with the emergence of new schools which have an impact on the competition of educational immigrants. follow the existing market share (what is there when this is desired by consumers). Provide the best service to the customer. the availability of ideal facilities in conducting research, such as space, liquid crystal display, system issues, mother-books, papers, and other ideas. The implementation of human resource development management in improving the quality of education at SD Negeri 170 OKU As an issue of an if the normal educational institution, in the implementation of education it is very important that there is an increase in quality is as an answer to the needs of ideas and ideals of a society that is developing so that increasing the quality of ideas can be realized through faith man. School services can be said to be of quality or quality if they have met the standard. This means that the product must exactly match the aims of education. In principle, the quality of education can be viewed as an issue of state, condition, appearance or performance that is shown by each component of the educational unit in achieving that objective that has been defined.

The implementation of the development of religious ideals needs to be done in a planned and sustainable manner. For development to be carried out properly, it must first be determined that the issue of a development program is the source of the human ideal. And to define a development program, management is needed to study a series of activities that are directed to utilize the resources of organizational ideals or institutions that are effective and efficient, through planning, organizing, giving orders / directing ideas and supervision

\section{Quality of Education SD Negeri $170 \mathrm{OKU}$}

The intended implementation is an issue of an activation process of realizing anything that has been planned to increase teacher immunity. The implementation phase basically answers as to how all management functions are as an issue in the process to achieve that institutional goal which has been determined through collaboration with other people who think about the source of ideas that exist, the idea can work as it should be (effective and efficient) for improvement. The implementation of increasing teacher immunity is aimed at increasing the ability to be independent (for certain matters) without too much dependence on other parties. The implementation of increasing teacher immunity must also establish collaborations or partnerships with stakeholders to produce optimal goals. Likewise, the issue of a program that must be implemented by involving all parties proportionally and professionally, thereby increasing the enthusiasm for participation. The implementation of teacher quality at SD Negeri 170 OKU is, among other things, done by including teachers in scientific forums (seminars, education and training, workshops, workshop and courses), further studies, revitalization of teacher working group, a forum for friendship between teachers, welfare benefits, provision of supporting facilities such as the provision of facilities. on the internet to access new mother information, buy new mothers who support teacher performance, this is as described by $\mathrm{Mr} \mathrm{EW}$ as follows: "Programs or efforts to improve the quality of teachers that I do as the principal assisted by the vice-principal and related staff is including seminars, education and training, courses, teacher working group, further studies, improving the welfare of teachers, providing supporting facilities such as the internet and supporting new reading books and we form a forum for friendship between teachers.

In detail, the efforts to foster and develop teacher immigrants carried out by the Principal of SD Negeri 170 OKU are as follows: hold ideas and include teachers in scientific 
forums (education and training (upgrading / in-service training), workshops, and seminars). Education and training (in-service training/upgrading) are one of the ways to improve teacher professionalism. In addition to enhancing the ability of teacher performance in teaching and learning activities, education and training are also useful for teachers to get new information related to education, teaching, new methods in the field of learning as well as being useful for teachers who are compiling teacher certification portfolios additional points to meet the points set for achieving graduation.

Regarding this, the results of an interview with the principal of SD Negeri 170 OKU, Mr EW said: "In order to improve teacher performance, we always send teachers in turns and in accordance with their field of study to attend training, seminars, workshops, workshops or other educational activities. whether held by the education and training centre (government), private organizers or training held independently by schools. Furthermore, the principal of SD Negeri 170 OKU explained that in order to improve teacher performance in January 2019, SD Negeri 170 OKU held a training on Classroom Action Research independently.

\section{Conclusion}

Based on the results of research and overall discussion of "human resources management in the context of improving the quality of education at 170 OKU public elementary schools". It can be concluded that the existing managerial system is not singlecentered, in this case the principal is assisted by a designated person.

In general, human resource planning is carried out by carrying out the analysis of all the activities or work expenses that must be done by all the components of the school. The results of the analysis are expressed in the main tasks and functions (the main objective of the function) which is the description of job analysis or job management. Based on the results of the analysis of this position or work, it is ideal to fill in and placement of personnel in positions in accordance with intellectual capacity, capability, work experience and peerto-peer placement.

The ideal pattern that was developed in the effort to carry out the recruitment and selection of non-permanent teacher candidates was carried out based on the consideration of academic, non-academic, good character, and putting aside the relationship of kinship or in other words, prioritizing achievement and professionalism rather than co-coism.

The developmental training program is not all planned with the same mind as the immature idea, the idea that is done outside and within the ideal. This seems to give the impression that the program is just following the trend and only following the conditions that developed at that time.

In relation to the training and human resource development that has been carried out during this time, the evaluation that is done is still likely to measure the success and failure of training from the implementation strategy, not oriented to whether effectively the training being carried out is able to change the ideal behavior if it changes the ideal behavior and if there is an increase in behavior, is it true?, Ttat was due to the training that was followed.

Although the last evaluation is done using three stages, namely; (1) monthly evaluation, (2) evaluated in the middle of semester, (3) evaluated at the end of the year, but still there is an imbalance between the trips and the implementation of the program itself. This results in Tupoksi is a standard of work which is used as a measure of the success of the business; and is an educator who performs tasks for which his responsibility is ignored. 
With the ideal idea and the method of evaluation that is used is that the head of the school has met the minimum standard, but the only thing is that there are a few miscalculations, it is precisely the value factor. Even though the ideal assessment is judged by the head of the school who is the ideal person who is pointing out, it is the right side of the approach. Specifically, evaluating the performance of civil servants using employee work goals as a measure for assessing applicative adherence because it is not based on Tupoksi is the standard for teacher work with the standard of employee work. Therefore, it is not appropriate to use the same measurement tool to measure the type of work, the burden of work and different responsibilities.

In general, the compensation system that exists in sd negeri $170 \mathrm{oku}$ can be concluded that the system provides honoraria for teachers and employees. as has been explained earlier, that for civil servant teachers, the salary is paid by the government according to their rank and rank. meanwhile, the non-permanent teacher is paid through the bos plan and the student's guardian donation, as well as structural goals, nonpermanent teacher incentives from the district or province, thr and for civil servants there is a 13th salary, adjusted to the ability of the school. regarding the non-permanent teacher honorarium budget for an average non-permanent teacher honorarium of Rp.350,000.00Rp.450,000.00 per month, so if compared to the regional minimum wages in this regency, it is still very concerning. so that in the coming year there will be an increase in their honorarium and welfare and rights.

In general, surveillance is carried out by referring to the laws and regulations that have been mutually agreed upon. The supervision system in SD Negeri $170 \mathrm{OKU}$ is by determining standards, supervising activities, checking and comparing results with standard and correcting activities or activities. The supervisory system is carried out administratively and the supervision is direct, it means that the supervision of the performance is adjusted to the standard $i$ that has been determined the head of the school and the person who is appointed directly the idea of looking at the idea of observing the performance of the teacher and employee. Supervision at SD Negeri 170 OKU under the leadership of the school principal with the assistance of several people who have been appointed. Supervision is done with administrative monitoring both monthly, even at any time.

\section{References}

Almasri, M. N. (2017). Manajemen Sumber Daya Manusia: Imlementasi Dalam Pendidikan Islam. Kutubkhanah, 19(2), 133-151. http:// ejournal.uin-suska.ac.id/index.php/Kutubkhanah/article/view/2547.

Amalia, D. (2014). Pengaruh Karakteristik Perusahaan Terhadap Corporate Social Responsibility Disclosure di Bursa Efek Indonesia. Media Riset Akuntansi, 3(1), Hal34.

Fathoni. (2006). Manajemen Sumber Daya Manusia. Bandung: Rineka Cipta.

Iskarim, M. (2017). Rekrumen Pegawai: Starting-Point Menuju Kinerja Organisasi Yang Berkualitas Dalam Perspektif Manajemen Sumber Daya Manusia dan Islam. 
Manageria: Jurnal Managemen Pendidikan Islam, 2 (2), pp. 307-327. http:// ejournal.uinsuka.ac.id/tarbiyah/index.php/manageria/article/view/1620

Kemal, I., \& Hasibuan, R.A. (2017). Manajemen Kewirausahaan Melalui Strategi Berbasis Sekolah Di Islamic Solidarity School. Jurnal Akuntabilitas Manajemen Pendidikan, 5 (1), pp. 71-81. https://journal.uny.ac.id/index.php/jamp/article/view/11550

Kemal, I., Suryadi., \& Rosyidi, U. (2019). Management of Lecturers Resources Development at Higher Education. International Journal of Higher Education, 8 (5), pp. 246-256. http://www.sciedupress.com/journal/index.php/ijhe/article/view/16014

Mangkuprawira, S. (2008). Standar Kompetensi dan Sertifikasi Guru. Bandung: PT. Remaja

Mufidah, Y.I. (2018). Pengembangan Sumber Daya Pendidik. Ta'dibia: Jurnal Ilmiah Pendidikan Agama Islam, 8 (1), pp. 75-84.

http://jurnal.stitradenwijaya.ac.id/index.php/tdb/article/view/97

Nasution S, (1992). Penelitian Naturalistik Kualitatif. Bandung: Tarsito.

Ruhana, Ika. (2012). Pengembangan Kualitas Sumber Daya Manusia VS Daya Saing Global. Profit: Jurnal Administrasi Bisnis, 6 (1), pp. 50-56. https://profit.ub.ac.id/index.php/profit/article/view/134

Suryadi., Nurhattati., Sawan, F., Fadhillah., Kemal, I., \& Rachmadtullah, R. (2020). How Is The Relationship Of Self-Concept To The Social Competence Ability Of Elementary School. Journal of Advanced Research in Dynamical and Control Systems, 12 (6), pp. 2782-2787.

https: / /jardcs.org/archivesview.php?volume=3\&issue=36\&page $=12$

Widiansyah. (2018). Peranan Sumber Daya Pendidikan Sebagai Faktor Penentu Dalam Manajemen Sistem Pendidikan. Cakrawala: Jurnal Humaniora Bina Sarana Informatika, 18 (2), pp. 229-234.

https://ejournal.bsi.ac.id/ejurnal/index.php/cakrawala/article/view/4347

Winarti, E. (2018). Perencanaan Manajemen Sumber Daya Manusia Lembaga Pendidikan. Tarbiyatuna: Jurnal Pendidikan Ilmiah, 3 (1), pp. 1-26.

http://ejournal.kopertais4.or.id/mataraman/index.php/tarbiyatuna/article/view $\angle 3434$

Yuniarti, D. (2019). Pengaruh Pelatihan dan Pengembangan Sumber Daya Manusia Dalam Meningkatkan Kinerja Guru Pada SMK Negeri 1 Muntok. Efektor, 6 (1), pp. 98-106. https://doi.org/10.29407/e.v6i1.12794 